\title{
Proliferation-Associated Expression of the MEN1 Gene as Revealed by In Situ Hybridization: Possible Role of the Menin as a Negative Regulator of Cell Proliferation Under DNA Damage
}

\author{
Yasuto Ikeo, Akihiro Sakurai, Rieko Suzuki, Mu-Xia Zhang, Shigeki Koizumi, \\ Yuichiro Takeuchi, Wataru Yumita, Jun Nakayama, and Kiyoshi Hashizume \\ Department of Aging Medicine and Geriatrics (YI, AS, RS, WY, KH), Department of Laboratory Medicine (MZ, YT, \\ $J N$ ), and Department of Hygiene and Medical Genetics (SK), Shinshu University School of Medicine, Matsumoto, \\ Japan
}

SUMMARY: The gene responsible for multiple endocrine neoplasia type 1 (MEN1) has recently been identified. Wide expression of the MEN1 gene in endocrine and non-endocrine organs examined by northern blotting has been reported, but the detailed cellular distribution of the MEN1 transcript in each tissue has not yet been examined in any species. In this report, expression of the MEN1 gene in adult human tissues was studied by in situ hybridization. The MEN1 transcript was widely observed in all tissues examined, and an enhanced expression in relation to cell proliferation was seen in some organs. Cell cycle arrest at the G1-S border reduced the MEN1 mRNA level to less than $50 \%$ of that in exponentially growing asynchronous cells. The expression increased as cells entered into S phase, indicating cell cycle-associated transcriptional regulation of the MEN1 gene. Increase or decrease of the amount of menin did not affect proliferation of $\mathrm{CHO}$ cells under normal conditions. However, when cells were exposed to the DNA-cross-linking agent, diepoxybutane, overexpression of wild-type menin inhibited DNA synthesis. This effect was not observed when cells were exposed to ultraviolet light. These results suggest that menin may negatively regulate cell cycle under certain DNA damage. (Lab Invest 2000, 80:797-804).

\begin{abstract}
$M$ ultiple endocrine neoplasia type 1 (MEN 1) is an autosomal dominantly inherited disease causing a predisposition to hyperplastic and neoplastic disorders arising from the parathyroid, anterior pituitary, and endocrine pancreas (Thakker, 1998). The gene responsible for MEN 1, designated MEN1, has recently been identified (Chandrasekharappa et al, 1997; The European Consortium on MEN1, 1997). Germline mutations of the MEN1 gene have been identified in most subjects with familial and sporadic MEN 1 (Bassett et al, 1998; Chandrasekharappa et al, 1997; Giraud et al, 1998; The European Consortium on MEN1, 1997). Mutation of the MEN1 gene along with the loss of unaffected allele in tumors of patients indicates that this gene functions as a tumor suppressor and that the loss of both alleles leads to tumor development (Knudson, 1985). More than 200 germline and somatic mutations of the MEN1 gene have been identified to date but no apparent hot spots or genotype-phenotype correlations have been observed, providing little clue to either the physiological
\end{abstract}

Received December 2, 1999.

Address reprint requests to: Dr. A. Sakurai, Department of Aging Medicine and Geriatrics, Shinshu University School of Medicine, 3-1-1 Asahi, Matsumoto, 390-8621 Japan. Fax: 8126337 2710; E-mail: bakabon@hsp.md.shinshu-u.ac.jp function or the domain structure of the MEN1 gene product, menin (Chandrasekharappa et al, 1997). Menin has been demonstrated to be a nuclear protein (Guru et al, 1998) which functionally interacts with the AP1 transcription factor JunD (Agarwal et al, 1999; Gobl et al, 1999). The wide expression of the Men1 transcript in early stage of mouse embryogenesis suggests that this gene may play a role in fetal development (Bassett et al, 1999; Stewart et al, 1998). In humans, the ubiquitous expression of the MEN1 gene in endocrine and non-endocrine organs, as examined by northern blotting, has been reported (The European Consortium on MEN1, 1997), but the detailed cellular distribution of the MEN1 transcript in each tissue has not been examined in any species. To elucidate this issue and to understand the role of menin in cell physiology and tumorigenesis, we have examined expression of the MEN1 gene in adult human tissues by in situ hybridization. The MEN1 transcript was widely observed in various organs regardless of their origin. Interestingly, cell proliferation-associated expression of MEN1 was observed in some organs. This was also confirmed by synchronization of cultured cells. Analysis of DNA synthesis in cultured cells revealed that overexpression of menin inhibited DNA synthesis when cells were exposed to a DNA-cross-linking agent, but not to 
ultraviolet light. Menin may play a role in cell cycle regulation or DNA repair under certain conditions.

\section{Results}

Expression of the MEN1 transcript in various adult human tissues was examined by in situ hybridization using a 150 base pair riboprobe containing an antisense MEN1 cDNA sequence (see Materials and Methods). A list of examined tissues and the results of the in situ hybridization is summarized in Table 1. As depicted in Figure 1, the MEN1 transcript was widely observed in various organs regardless of their origin. No hybridization was detected when the sense probe was used. Weak and homogenous hybridization was observed in lung, liver, kidney, spleen, mammary gland, and thyroid. In kidney, no apparent difference of expression levels was seen between glomeruli and tubuli (Fig. 1A). In pancreas, moderately intense expression was observed in acinar cells, while expression in islet cells was weaker than that in acinar cells (Fig. 1C). Karges et al (1999) recently reported that MEN1 mRNA expression levels are high in rodent islet cells, while in other pancreas tissue, expression levels are low. The reason for the difference between our results and theirs is unclear. It may be because of species differences or differences in methods. The strongest expression we found was in placenta, where MEN1 expression was homogeneously observed (Fig. 1E). Intense expression was also found in the proliferative phase of endometrium and parabasal cells of the esophageal mucosa (Fig. 1, G and M). In contrast, only faint expression was seen in the secretory phase of endometrium (Fig. 1J). These findings imply that the MEN1 expression is enhanced in actively proliferating cells. Indeed, expression of Ki67, the marker of proliferative activity, was observed in areas where MEN1 expression is prominent (Fig. 1, I, L and O).

To investigate whether the MEN1 gene expression is cell proliferation dependent, COS cells were syn-

Table 1. Expression of the MEN1 Transcript in Normal Adult Tissues

\begin{tabular}{lc}
\hline \multicolumn{1}{c}{ Tissue } & MEN1 \\
\hline Lung & $+\sim++$ \\
Liver & \pm \\
Kidney & + \\
Spleen & + \\
Esophageal Mucosa (parabasal cell & +++ \\
$\quad$ layer) & \\
Esophageal Mucosa (other cells) & \pm++ \\
Duodenal Mucosa & ++ \\
Mammary Gland & + \\
Thyroid & + \\
Pancreas (acinar cells) & ++ \\
Pancreas (islet cells) & + \\
Endometrium (proliferative phase) & ++ \\
Endometrium (secretory phase) & \pm \\
Placenta & +++ \\
\hline
\end{tabular}

Staining intensity: \pm , very weak; + , weak; ++ , moderate; +++ , strong. chronized at the G1-S border by the addition of thymidine to the culture medium. Cells were then exposed for various periods to medium containing $20 \%$ FBS. Total RNA was isolated and used for northern blotting. As shown in Figure 2A, synchronization of cells at the G1-S border decreased MEN1 mRNA levels to $44 \%$ of that of exponentially growing asynchronous cells. MEN1 mRNA levels gradually increased as cells entered into $S$ phase, and returned to their initial levels 8 hours after stimulation. MEN1 mRNA levels were stable thereafter (data not shown).

These results indicate that the MEN1 gene is abundantly expressed where cells are actively proliferating and that MEN1 expression is partly regulated in a cell cycle-associated manner. To examine the significance of MEN1 gene expression on cell proliferation, $\mathrm{CHO}$ cell lines expressing wild-type or mutant menin, and a cell line with reduced menin expression were established. Expression of wild-type and mutant menin in each clone was confirmed by western blotting (Fig. 3A). Clones WT-3 and WT-12 expressed tagged wildtype menin, and FS-2 and FS-5 expressed mutant menin, which lacked carboxylterminus because of a frame shift mutation at amino acid codon 516 (lkeo et al, 1999). In clone Rev-1, established by transfection of cells with pcDNA/HisMeninRev, expression of endogenous menin was reduced to approximately $30 \%$ of that of control. pcDNA/HisMeninRev was generated by insertion of MEN1 cDNA into pcDNA3.1/HisC in the reverse direction, thus it is expected to reduce endogenous menin expression by RNA-RNA hybridization. Increase or decrease of the wild-type or mutant menin did not significantly affect cell growth, as demonstrated by the virtually equal growth rates of all cells (Fig. 3B). After 48 hours in culture, cell numbers of control cells were approximately 25 -fold greater than initially. Similar growth rates were observed in all other cells. This was confirmed by the uptake of bromodeoxyuridine (BrdU) in each cell line at various concentrations of FBS in the culture medium (Fig. 3C). These results indicate that, at least in $\mathrm{CHO}$ cells, menin does not exert a direct effect on cell proliferation and DNA synthesis. With $0.5 \%$ FBS, BrdU incorporation in WT-3, WT-12, FS-2, and FS-5 cells were lower compared with control $\mathrm{CHO}$ cells, but did not reach statistical significance (Fig. 3C).

It has previously been reported that lymphocytes from patients with MEN 1 show increased chromosome aberration when exposed to DNA-cross-linking agents (Sakurai et al, 1999; Tomassetti et al, 1995). Therefore, we examined the effect of menin expression on the cellular response to one such agents, diepoxybutane. As shown in Figure 4A, diepoxybutane decreased BrdU incorporation in a dose-dependent manner in all cells. Addition of $1 \mathrm{~nm}$ and $10 \mathrm{~nm}$ diepoxybutane in culture medium decreased the BrdU incorporation of control $\mathrm{CHO}$ cells to $52.0 \pm 13.3 \%$ and $30.9 \pm 3.6 \%$ (mean $\pm \mathrm{SD}$ ) of untreated cells, respectively. Diepoxybutane also decreased BrdU incorporation in other cell lines in a dose dependent manner. With $10 \mathrm{~nm}$ diepoxybutane, BrdU incorporation in WT-3 cells decreased to $18.1 \pm 5.2 \%$ of 

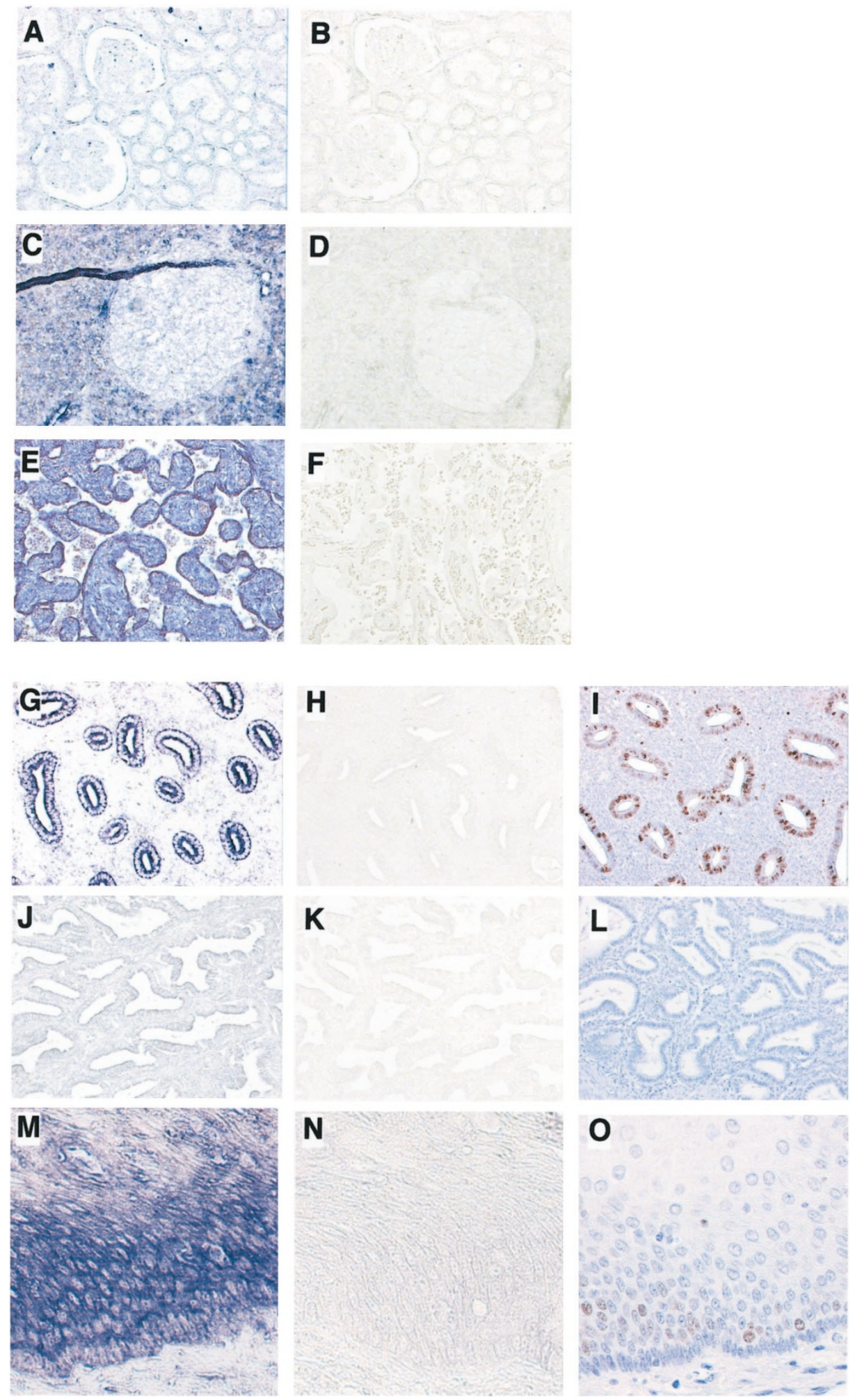

\section{Figure 1.}

Expression of the MEN1 transcript. A, B: kidney; C, D: pancreas; E, F: placenta; G, H, and I: proliferative phase of the endometrium; J, K, and L: secretory phase of the endometrium; $M, N$, and 0 : esophageal mucosa. $A, C, E, G, J$, and $M$ : in situ hybridization with an antisense probe; $B, D, F, H, K$, and N: in situ hybridization with a sense probe; I, L, and 0: Ki67 immunoreactivity. Note: MEN1 transcripts are abundantly expressed (G, M) where Ki67 immunoreactivity is present (I, 0).

untreated WT-3 cells, indicating that WT-3 is more sensitive to diepoxybutane than control $\mathrm{CHO}$ cells $(p=0.025)$. A similar result was also observed in WT-12 cells, although statistical significance was not obtained $(p=0.057)$. This is probably because WT-12 cells express less menin than WT- 3 cells. On the other hand, the decrease of menin expression in Rev-1 did not influence the inhibitory effect of diepoxybutane on 


\begin{tabular}{|c|c|c|c|c|c|c|c|}
\hline MEN1 & As & 0 & 0.5 & 1 & 2 & 4 & 8 (h) \\
\hline & & & & & & & \\
\hline $\begin{array}{l}\text { relative } \\
\text { amount }\end{array}$ & 100 & 44 & 42 & 52 & 60 & 64 & $95(\%)$ \\
\hline G0/G1 & 48 & 73 & & 67 & 64 & 57 & 52 \\
\hline $\mathbf{S}$ & 30 & 10 & & 14 & 18 & 21 & 22 \\
\hline G2/M & 22 & 17 & & 19 & 18 & 22 & 26 \\
\hline
\end{tabular}

Figure 2.

Effect of cell cycle arrest on MEN1 gene expression. COS cells were synchronized at the G1-S border by the addition of thymidine to the culture medium, then stimulated with $20 \%$ FBS for various periods of time, as indicated. Total RNA was prepared and used for northern blotting. Results of flow cytometric analysis at each point are also shown. As: asynchronous.

BrdU incorporation. Additionally, in FS-2 and FS-5 cells, the efficiency of diepoxybutane was not different than in control $\mathrm{CHO}$ cells. This inhibitory effect of wild-type menin on BrdU incorporation was specifically observed only in the presence of diepoxybutane. As shown in Figure 4B, exposure of cells to ultraviolet light reduced $\mathrm{BrdU}$ incorporation in a dose-dependent manner. Neither overexpression nor reduction of menin expression influenced the inhibitory effect of ultraviolet light on BrdU incorporation. Finally, to examine whether diepoxybutane affects the expression of endogenous menin, $\mathrm{CHO}$ cell nuclear extracts were prepared after exposure to either $10 \mathrm{~nm}$ diepoxybutane or ultraviolet light and menin levels were examined by western blotting. As shown in Figure 4C, exposure to either diepoxybutane or ultraviolet light did not significantly change the menin expression. No mobility shift of the protein, as is seen in the phosphoproteins, was seen.

\section{Discussion}

In the present study, we examined the detailed distribution of the MEN1 transcript in human adult tissues by in situ hybridization. Wide expression of the MEN1 gene in various tissues has previously been reported by northern blotting and western blotting (Bassett et al, 1999; Chandrasekharappa et al, 1997; Ikeo et al, 1999; Karges et al, 1999; Stewart et al, 1999), but the present study revealed that the distribution in each organ is not always even. Enhanced MEN1 expression was observed in regions where cells are actively proliferating (Fig. 1). Some tumor-suppressor gene products dramatically change their expression levels during cell cycle; by cellular stresses through regulation of mRNA expression or by affecting the stability of the protein (Andres et al, 1998; Bertwistle et al, 1997; McKay et al, 1998; Shier et al, 1997). With this knowledge and recent reports demonstrating abundant expression of the Men1 gene in fetus and testis (Bassett et al, 1999; Stewart et al, 1999), and with our present
A

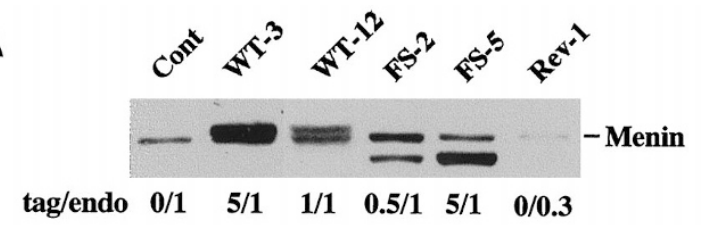

B
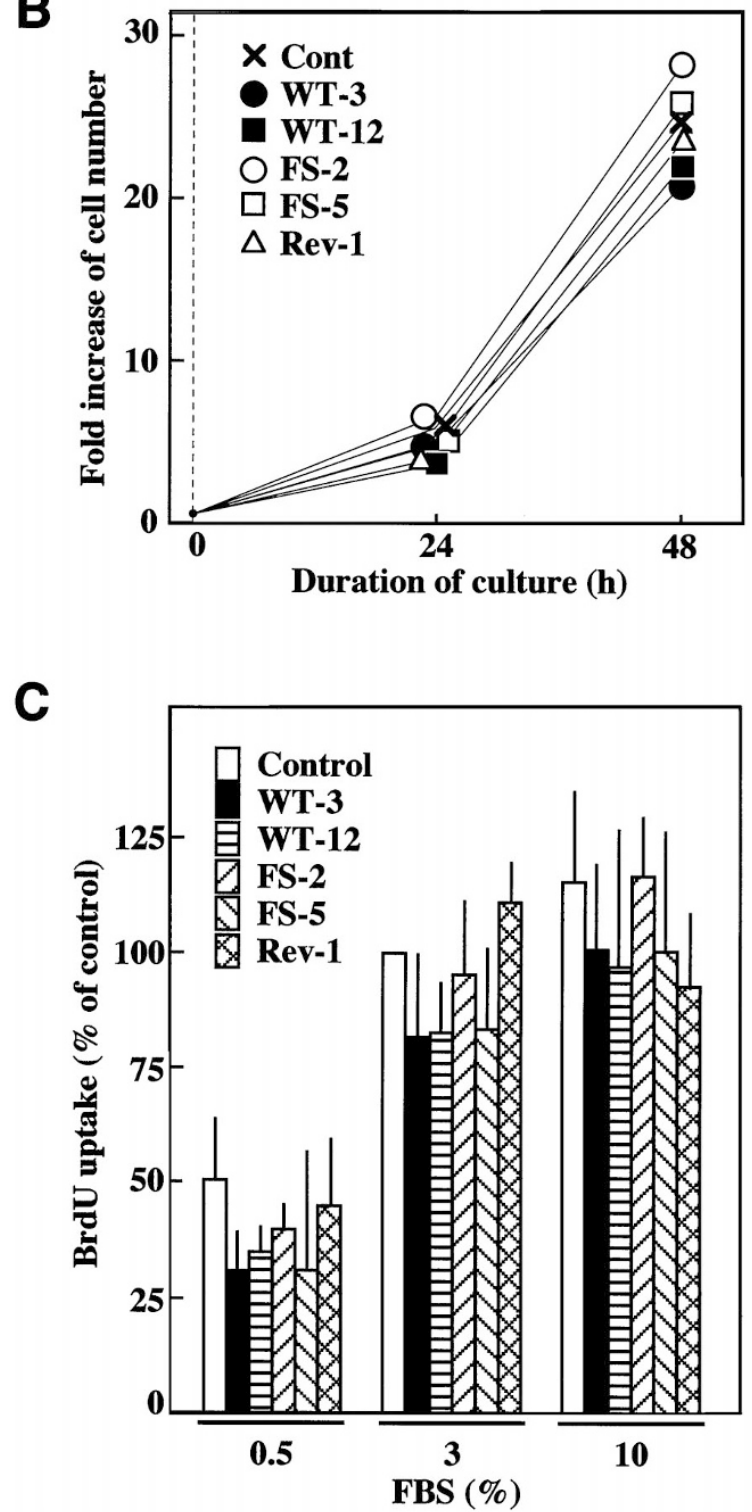

Figure 3.

Effects of menin expression on cell proliferation. A: Western blot showing expression of tagged and endogenous menin. Cont: cells transfected with pcDNA/3.1HisC. Note the slowly migrating tag-menin in WT-3 and WT-12 cells, and the rapidly migrating mutant tag-menin in FS-2 and FS- 5 cells. The relative amount of tagged menin and endogenous menin in each clone is shown below each lane. Ten micrograms of nuclear extract was loaded in each lane. The loading of equal amounts of protein was verified by ponceau staining of the membrane. B: Growth rate of cloned cells. Cells were cultured in medium containing $3 \%$ FBS and the cell number after the desired time in culture is expressed as the fold-increase from the initial value. The average of two independent experiments is shown. C: Bromodeoxyuridine (BrdU) incorporation of cloned cells cultured with various concentration of FBS. BrdU uptake in control cells with $3 \% \mathrm{FBS}$ is expressed as $100 \%$. Mean \pm SD of three experiments are shown. 

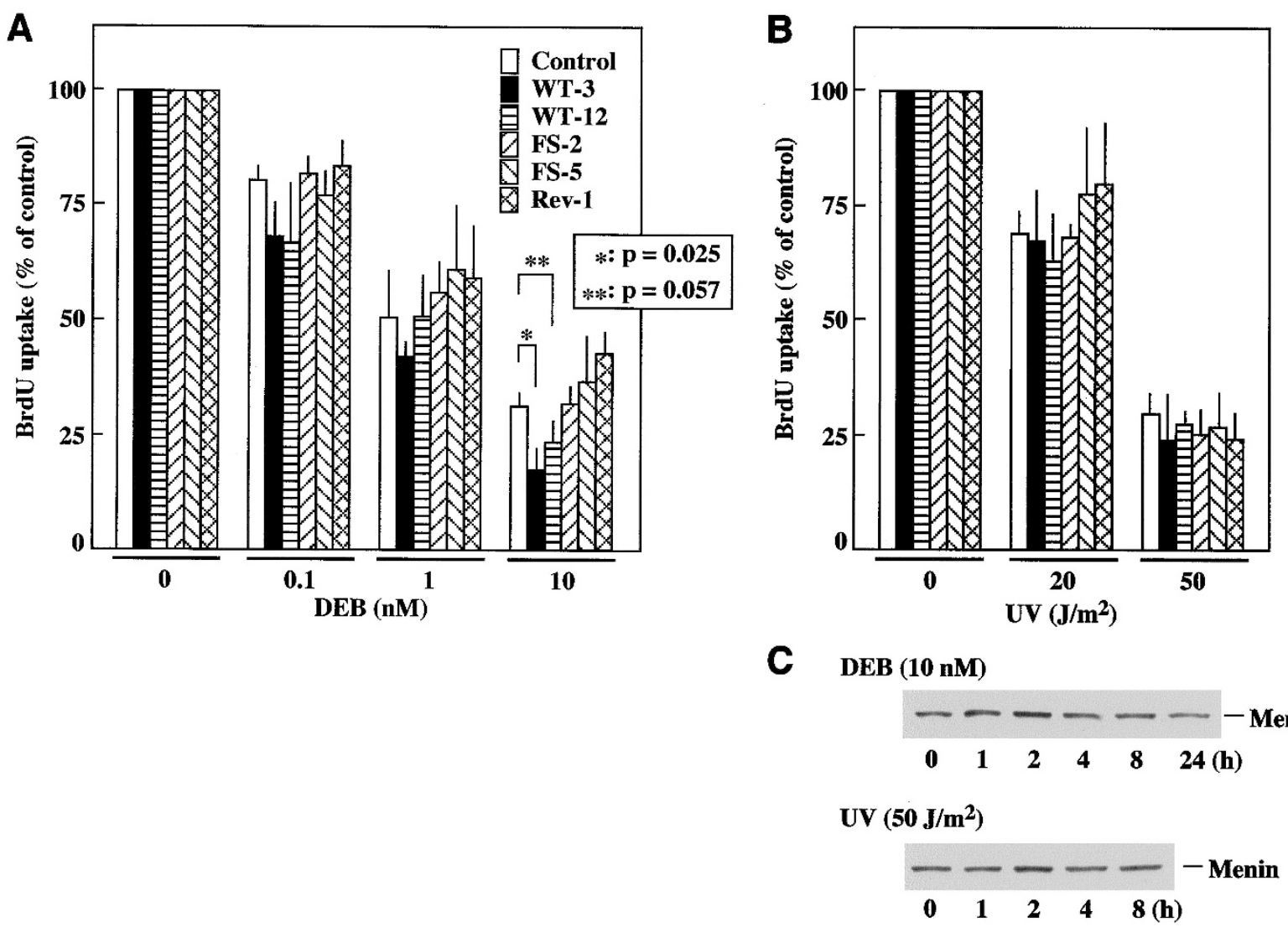

\section{Figure 4.}

$\mathrm{A}$ : BrdU incorporation of cloned cells cultured in the presence of diepoxybutane $(D E B)$. Uptake of BrdU in each cell line without diepoxybutane is expressed as $100 \%$. Mean \pm SD of three experiments are shown. B: BrdU incorporation of cloned cells after exposure to ultraviolet light. Uptake of BrdU in each cell line without ultraviolet exposure is expressed as $100 \%$. Mean \pm SD of three experiments are shown. C: Menin expression in $\mathrm{CHO}$ cells in the presence of $10 \mathrm{nM}$ diepoxybutane (DEB) or after exposure to $50 \mathrm{~J} / \mathrm{m}^{2}$ ultraviolet light (UV). Representative results of experiments repeated several times are shown.

results of in situ hybridization, we reasoned that MEN1 gene expression might be regulated in a cell cycledependent manner. Although the magnitude of fluctuation was not very dynamic as is seen in some tumor suppressor genes (Andres et al, 1998; Bertwistle et al, 1997; McKay et al, 1998; Shier et al, 1997), the MEN1 mRNA in cultured cells was decreased to less than $50 \%$ of the control level by halting cell cycle at the G1-S border (Fig. 2A).

We did not observe any effects of menin expression on cell proliferation under regular culture conditions (Fig. 3, B and C). However, overexpression of menin significantly inhibited DNA synthesis when cells were exposed to a DNA-cross-linking agent. These results indicate that the role of menin is not merely the acceleration or inhibition of cell proliferation under normal circumstances, but rather that it functions as a negative regulator of cell proliferation when DNA is damaged. Along with previous observations (Sakurai et al, 1999; Tomassetti et al, 1995) of chromosome aberration in lymphocytes from patients with MEN 1, it is possible that menin plays a role in the maintenance of DNA integrity or in repair of damaged DNA. The higher frequency of altered DNA copy numbers in parathyroid adenomas with MEN1 gene mutations and/or loss of heterozygosity than in adenomas without MEN1 involvement (Farnebo et al, 1999) also suggests that the MEN1 gene product may be important in maintaining DNA integrity. Increased sensitivity to DNA-cross-linking agents is the cardinal feature observed in patients with Fanconi anemia (FA) (Ishida and Buchwald, 1982), an autosomal recessive disorder characterized by bone marrow failure, cancer susceptibility, and a variety of developmental defects. This disease is genetically heterogeneous and patients can be classified into eight complementation groups (FA A-H) by somatic-cell hybrid analysis; only three of eight responsive genes (FANCA, FANCC and FANCG) have been cloned (Carreau and Buchwald, 1998; de Winter et al, 1998). Cell cycle-dependent expression of FANCC protein and nuclear colocalization of FANCA/FANCC complex have been reported (Kupfer et al, 1997a, b). Menin might directly or indirectly interact with these $F A$ gene products and affect their function. The significance of the cell cycleassociated expression of the MEN1 gene and molecular mechanisms by which menin inhibits DNA synthesis after exposure to DNA-cross-linking agents awaits future elucidation.

Expression of the MEN1 gene in non-endocrine tissues as well as in endocrine organs raises questions about the mechanisms of the tumorigenesis in target organs in MEN 1. Despite its wide expression, involvement of menin is known only in endocrine tumors, 
foregut carcinoids, and cutaneous tumors (Böni et al, 1998; Marx et al, 1998). Additionally, the physiological significance of different levels of expression in different tissues is unclear. Recent reports revealed that menin plays a role in transcriptional regulation through interaction with the AP1 transcription factor JunD (Agarwal et al, 1999; Gobl et al, 1999). Because JunD functions as a negative regulator for cell growth and antagonizes ras-induced transactivation (Pfarr et al, 1994; Wang et al, 1996), the antagonistic effect of menin on JunD function and its role as a tumor suppressor seemed paradoxical. Recently, a suppressive effect of menin on the ras-mediated tumor phenotype in vivo and in vitro has been reported from the same group (Kim et al, 1999). The previously reported JunD function could be the consequence of the synergistic interaction of JunD and menin, rather than the function of JunD itself. Alternatively, menin could exert its tumor-suppressor function through interaction with JunD. Although MEN 1 is manifested in organ-specific neoplastic disorders, neither menin nor JunD shows an endocrine organ-specific distribution. Furthermore, an increased prevalence of ras-mediated tumors, such as pancreatic adenocarcinoma (Villanueva et al, 1996) and lung adenocarcinoma (Salgia and Skarin, 1998), is not found in patients with MEN 1. There might be a functional interaction between menin and regulatory nuclear protein(s) other than JunD, which are expressed in an organ-specific manner. It is also possible that the function of menin is regulated by a tissue-specific posttranslational modification. Alternatively, in a physiological environment, menin may be redundant in non-endocrine organs, where other proteins may compensate for the function of menin.

During preparation of this manuscript, Kaji et al (1999) reported cell cycle dependent fluctuation of menin level in $\mathrm{GH} 4 \mathrm{C} 1$ cells. Their observation agrees with our present results, but do not support the previous report by Guru et al (1999), demonstrating constant expression of menin throughout the cell cycle in NIH3T3 cells. The reason for the apparent differences between these reports is not clear. The cell cycle-dependent change of menin expression may be a cell-specific phenomenon, or the observation of quantitative change of translation product may be difficult because of the long half-lives of both MEN1 mRNA and menin. The half-life of menin in COS cells, estimated by cycloheximide treatment, is approximately 10 hours (lkeo et al, 1999) and that of MEN1 mRNA, estimated by actinomycin D treatment, is approximately 24 hours (data not shown). The halflives of MEN1 mRNA and menin in other cells are not known. It is also unknown whether the fluctuation of MEN1 mRNA parallels the fluctuation of menin.

In conclusion, we found that the MEN1 gene expression is regulated in a cell cycle-associated manner, to some extent. The inhibitory effect of overexpressed menin on DNA synthesis after exposure to a DNA-cross-linking agent implies that menin may function not only as a "gatekeeper" but also as a "caretaker" (Kinzler and Vogelstein, 1997). Future elucidation of the function of menin should enable a better understanding of the pathogenesis of MEN 1 and subsequently lead to better clinical management of patients with MEN 1.

\section{Materials and Methods}

\section{Preparation of a MEN1-Specific RNA Probe}

A part of the MEN1 cDNA encoding amino acids 431 to 480 of menin (Chandrasekharappa et al, 1997) was amplified by polymerase chain reaction using pCMVsportMenin (generously provided by Dr. S. C. Chandrasekharappa), containing full-length human MEN1 cDNA, as a template. This amplicon was subcloned into the Xbal and Asp718 sites of pGEM-3Zf (+) (Promega, Madison, Wisconsin). This construct was linealized with $X b a l$, and a digoxigenin-labeled antisense RNA probe was prepared using T7 RNA polymerase and a DIG RNA labeling kit (Boehringer Mannheim, Mannheim, Germany). A sense probe was similarly obtained with SP6 RNA polymerase using Asp718-digested plasmid as a template.

\section{In Situ Hybridization}

Normal human tissue specimens obtained at surgery were subjected to in situ hybridization. After the tissue sections were deparaffinized in xylene, hydrated slides were immersed in $0.2 \mathrm{M} \mathrm{HCl}$ for 20 minutes and then digested with proteinase $\mathrm{K}$, followed by postfixation with $4 \%$ paraformaldehyde. These slides were rinsed with $2 \mathrm{mg} / \mathrm{ml}$ of glycine and subsequently acetylated for 10 minutes in $0.25 \%$ acetic anhydride in $0.1 \mathrm{M}$ triethanolamine $(\mathrm{pH}$ 8.0). The hydrated slides were defatted with chloroform and air-dried. After prehybridization with $50 \%$ deionized formamide and 2x SSC for 1 hour at $45^{\circ} \mathrm{C}$, the slides were hybridized with $0.5 \mathrm{mg} / \mathrm{ml}$ antisense or sense probe in $50 \%$ deionized formamide, $2.5 \mathrm{~mm}$ EDTA (pH 8.0), 300 mm $\mathrm{NaCl}, 1 \mathrm{X}$ Denhardt's solution, 10\% dextran sulfate, and $1 \mathrm{mg} / \mathrm{ml}$ of brewer's yeast tRNA at $45^{\circ} \mathrm{C}$ for 16 hours. After hybridization, the slides were washed in $50 \%$ formamide and $2 \times$ SSC for 1 hour at $45^{\circ} \mathrm{C}$ and digested with $10 \mathrm{mg} / \mathrm{ml}$ of RNase $A$ at $37^{\circ} \mathrm{C}$ for 30 minutes. After washing with 2x SSC and $50 \%$ formamide at $45^{\circ} \mathrm{C}$ for 1 hour, 1x SSC and $50 \%$ formamide at $45^{\circ} \mathrm{C}$ for 1 hour, and $1 \times$ SSC and $50 \%$ formamide at room temperature for 30 minutes, the sections were subjected to immunohistochemistry for detection of the hybridized probes using an alkaline phosphatase-conjugated anti-digoxigenin antibody (Boehringer Mannheim). The alkaline phosphatase reaction was visualized with 5-bromo-4-chloro-3-indolyl phosphate and nitroblue tetrazolium.

\section{Immunohistochemistry}

Deparaffinized tissue slices were subjected to indirect immunohistochemistry with the Ki67 antibody (Dako, Kyoto, Japan). For the secondary antibody, goat antirabbit immunoglobulin-G antibody conjugated with horse-radish peroxidase (Dako) was used, and perox- 
idase activity was visualized with a diaminobenzidinehydrogen peroxide solution.

\section{Northern Blotting}

Total RNA was isolated from cultured COS cells using the RNAqueous total RNA isolation kit (Ambion, Austin, Texas). To halt cell growth, cells were cultured in medium supplemented with $3 \mathrm{~mm}$ thymidine for 14 hours, followed by incubation in fresh thymidine-free medium for 10 hours. Cells were again cultured with 3 mм thymidine for an additional 12 hours, then stimulated by medium supplemented with $20 \%$ FBS. After incubation for the desired time, cells were harvested and total RNA was isolated. Ten micrograms of total RNA was separated by agarose gel electrophoresis, blotted onto Hybond-N+ (Amersham, Buckinghamshire, United Kingdom), and hybridized with a ${ }^{32} \mathrm{P}$ labeled $1.4 \mathrm{~kb}$ Xhol MEN1 cDNA fragment. A GAPDH probe was used as a control for RNA preparation and loading. After hybridization under standard conditions, membranes were washed and air-dried, and hybridized radioactivity was detected by the Bioimaging Analyzer System BAS1500 (Fuji Photo Film, Tokyo, Japan).

\section{Flow Cytometric Analysis}

COS cells cultured as described above were harvested and stained with propidium iodide. The cell population at each point was analyzed by FACScan (Becton Dickinson, Oxnard, California).

\section{Western Blotting}

Ten micrograms of nuclear extract was separated on a $10 \%$ SDS-polyacrylamide gel and blotted onto a nitrocellulose membrane (Hybond-C extra, Amersham). The membrane was blocked in Tris-buffered saline with $0.05 \%$ Tween 20 (TBS-T) containing 5\% skim milk for 1 hour followed by incubation with an antimenin antibody (HGK) diluted 1:2000 in TBS-T containing 1\% skim milk for 2 hours at room temperature. HGK was developed by immunizing rabbits by synthetic peptide corresponding to amino acids 199 to 212 of menin (lkeo et al, 1999). After several washes in TBS-T, the bound antibody was detected with peroxidase-coupled anti-rabbit IgG antibody and ECL Western blotting detection reagents (Amersham).

\section{Establishment of Transfected Cell Lines and Monitoring of Cell Growth}

$\mathrm{CHO}$ cells were grown in F-12 medium (Gibco, Rockville, Maryland) supplemented with 10\% FBS to subconfluence. Cells were transfected with either pcDNA/HisMenin, pcDNA/HisMenin516FS, pcDNA/HisMeninRev, or pcDNA3.1/HisC (Invitrogen, Carlsbad, California). Details of pcDNA/HisMenin and pcDNA/HisMenin516FS have been described previously (Ikeo et al, 1999). pcDNA HisMeninRev was generated by inserting MEN1 cDNA into pcDNA3.1/HisC in the reverse direction. Transfection was performed using Lipofectamine (Gibco) accord- ing to the manufacturer's instructions. Transfected cells were selected in medium containing $500 \mu \mathrm{g} / \mathrm{ml}$ of G418 (Nacalai Tesque, Kyoto, Japan). In each established cell line, expression of $\mathrm{N}$-terminal-tagged wild-type menin or $\mathrm{N}$-terminal-tagged mutant menin (516FS) as well as inhibition of endogenous menin expression by pcDNA HisMeninRev was examined by western blotting, as described above. To monitor the DNA synthesis of each clone, $3 \times 10^{3}$ cells were seeded into a 96-well ELISA plate in F-12 medium containing $3 \%$ FBS, unless otherwise indicated. The indicated amount of diepoxybutane (Sigma, St Louis, Missouri) was also added when necessary. The next day, the uptake of bromodeoxyuridine (BrdU) was estimated using Cell Proliferation ELISA, BrdU kit (Boehringer Mannheim) according to the manufacturer's instructions. To examine the effect of ultraviolet light, cells were exposed to the indicated doses of ultraviolet light immediately before the addition of BrdU.

\section{Acknowledgements}

Authors wish to thank Dr. S. C. Chandrasekharappa (NHGRI) for providing pCMVsportMenin.

\section{References}

Agarwal SK, Guru SC, Heppner C, Erdos MR, Collins RM, Park SY, Saggar S, Chandrasekharappa SC, Collins FS, Spiegel AM, Marx SJ, and Burns AL (1999). Menin interacts with the AP1 transcription factor JunD and represses JunDactivated transcription. Cell 96:143-152.

Andres JL, Fan S, Turkel GJ, Wang J-A, Twu N-F, Yuan R-Q, Lamszus K, Goldberg ID, and Rosen EM (1998). Regulation of BRCA1 and BRCA2 expression in human breast cancer cells by DNA-damaging agents. Oncogene 16:2229-2241.

Bassett JHD, Forbes SA, Pannett AAJ, Lloyd SE, Christie PT, Wooding C, Harding B, Besser GM, Edwards CR, Monson JP, Sampson J, Wass JAH, Wheeler MH, and Thakker RV (1998). Characterization of mutations in patients with multiple endocrine neoplasia type 1. Am J Hum Genet 62:232-244.

Bassett JH, Rashbass P, Harding B, Forbes SA, Pannett AA, and Thakker RV (1999). Studies of the murine homolog of the multiple endocrine neoplasia type 1 (MEN1) gene, men1. J Bone Miner Res 14:3-10.

Bertwistle D, Swift S, Marston NJ, Jackson LE, Crossland S, Crompton MR, Marshall CJ, and Ashworth A (1997). Nuclear localization and cell cycle regulation of the BRCA2 protein. Cancer Res 57:5485-5488.

Böni R, Wortmeyer AO, Pack S, Park W-S, Burg G, Hofbauer G, Darling T, Liotta L, and Zhuang Z (1998). Somatic mutations of the MEN1 tumor suppressor gene detected in sporadic angiofibromas. J Invest Dermatol 111:539-540.

Carreau M and Buchwald M (1998). Fanconi's anemia: What have we learned from the genes so far. Mol Med Today 4:201-206.

Chandrasekharappa SC, Guru SC, Manickam P, Olufemi S-E, Collins FS, Emmert-Buck MR, Debelenko LV, Zhuang Z, Lubensky IA, Liotta LA, Crabtree JS, Wang Y, Roe BA, Weisemann J, Boguski MS, Agarwal SK, Kester MB, Kim YS, Heppner C, Dong Q, Spiegel AM, Burns AL, and Marx SJ (1997). Positional cloning of the gene for multiple endocrine neoplasia-type 1. Science 276:404-407. 
de Winter JP, Waisfisz Q, Rooimans MA, van Berkel CG, Bosnoyan-Collins L, Alon N, Carreau M, Bender O, Demuth I, Schindler D, Pronk JC, Arwert F, Hoehn H, Digweed M, Buchwald M, and Joenje H (1998). The Fanconi anaemia group G gene FANCG is identical with XRCC9. Nat Genet 20:281-284.

Farnebo F, Kytölä S, Teh BT, Dwight T, Wong FK, Höög A, Elvius M, Wassif WS, Thompson NW, Farnebo L-O, Sandelin $\mathrm{K}$, and Larsson C (1999). Alternative genetic pathways in parathyroid tumorigenesis. J Clin Endocrinol Metab 84:37753780.

Giraud S, Zhang CX, Serova-Sinilnikova O, Wautot V, Salandre J, Buisson N, Waterlot C, Bauters C, Porchet N, Aubert J-P, Emy P, Cadiot G, Delemer B, Chabre O, Niccoli P, Leprat F, Duron F, Emperauger B, Cougard P, Goudet P, Sarfati E, Riou J-P, Guichard S, Rodier M, Meyrier A, Caron P, Vantyghem M-C, Assayag M, Peix J-L, Pugeat M, Rohmer V, Vallotton M, Lenoir G, Gaudray P, Proye C, Conte-Devolx B, Chanson P, Shugart YY, Goldgar D, Murat A, and Calender A (1998). Germ-line mutation analysis in patients with multiple endocrine neoplasia type 1 and related disorders. Am J Hum Genet 63:455-467.

Gobl AE, Berg M, Lopez-Egido JR, Öberg K, Skogseid B, and Westing $G$ (1999). Menin represses JunD-activated transcription by a histone deacetylase-dependent mechanism. Biochim Biophys Acta 1447:51-56.

Guru SC, Crabtree JS, Brown KD, Dunn KJ, Manickam P, Prasad NB, Wangsa D, Burns AL, Spiegel AM, Marx SJ, Pavan WJ, Collins FS, and Chandrasekharappa SC (1999). Isolation, genomic organization, and expression analysis of Men1, the murine homolog of the MEN1 gene. Mamm Genome 10:592-596.

Guru SC, Goldsmith PK, Burns AL, Marx SJ, Spiegel AM, Collins FS, and Chandrasekharappa SC (1998). Menin, the product of the MEN1 gene, is a nuclear protein. Proc Natl Acad Sci USA 95:1630-1634.

Ikeo Y, Sakurai A, and Hashizume K (1999). Characterization of the MEN1 gene product, menin, by site-specific polyclonal antibodies. Jpn J Cancer Res 90:1088-1095.

Ishida R and Buchwald M (1982). Susceptibility of Fanconi's anemia lymphoblasts to DNA-cross-linking and alkylating agents. Cancer Res 42:4000-4006.

Kaji H, Canaff L, Goltzman D, and Hendy GN (1999). Cell cycle regulation of menin expression. Cancer Res 59:50975101.

Karges W, Maier S, Wissmann A, Dralle H, Dosch HM, and Boehm BO (1999). Primary structure, gene expression and chromosomal mapping of rodent homologs of the MEN1 tumor suppressor gene. Biochim Biophys Acta 1446:286294.

Kim YS, Burns AL, Goldsmith PK, Heppner C, Park SY, Chandrasekharappa SC, Collins FS, Spiegel AM, and Marx SJ (1999). Stable overexpression of MEN1 suppresses tumorigenicity of RAS. Oncogene 18:5936-5942.

Kinzler KW and Vogelstein B (1997). Gatekeepers and caretakers. Nature 386:761-763.

Knudson AG Jr (1985). Hereditary cancer, oncogenes and antioncogenes. Cancer Res 45:1437-1445.
Kupfer GM, Yamashita T, Näf D, Suliman A, Asano S, and D'Andrea AD (1997a). The Fanconi anemia polypeptide, FAC, binds to the cyclin-dependent kinase, cdc2. Blood 90:10471054.

Kupfer GM, Näf D, Suliman A, Pulsipher M, and D'Andrea AD (1997b). The Fanconi anaemia proteins, FAA and FAC, interact to form a nuclear complex. Nat Genet 17:487-490.

Marx S, Spiegel AM, Skarulin MC, Doppman JL, Collins FS, and Liotta LA (1998). Multiple endocrine neoplasia type 1: Clinical and genetic topics. Ann Intern Med 129:484-494.

McKay BC, Ljungman M, and Rainbow AJ (1998). Persistent DNA damage induced by ultraviolet light inhibits p21 waf1 and bax expression: Implications for DNA repair, UV sensitivity and the induction of apoptosis. Oncogene 17:545-555.

Pfarr CM, Mechta F, Spyrou G, Lallemand D, Carillo S, and Yaniv M (1994). Mouse JunD negatively regulates fibroblast growth and antagonizes transformation by ras. Cell 76:747760.

Sakurai $A$, Katai $M$, Itakura $\mathrm{Y}$, Ikeo $\mathrm{Y}$, and Hashizume $\mathrm{K}$ (1999). Premature centromere division in patients with multiple endocrine neoplasia type 1. Cancer Genet Cytogenet 109:138-140.

Salgia R and Skarin AT (1998). Molecular abnormalities in lung cancer. J Clin Oncol 16:1207-1217.

Shier S-Y, Ikeda M, Taya Y, and Prives C (1997). DNA damage-induced phosphorylation of p53 alleviates inhibition by MDM2. Cell 91:325-334.

Stewart C, Parente F, Piehl F, Farnebo F, Quincey D, Silins G, Bergman L, Carle GF, Lemmens I, Grimmond S, Xian CZ, Khodei S, Teh BT, Lagercrantz J, Siggers P, Calender A, Van de Vem V, Kas K, Weber G, Hayward N, Gaudray P, and Larsson C (1998). Characterization of the mouse Men1 gene and its expression during development. Oncogene 17:24852493.

Thakker RV (1998). Multiple endocrine neoplasia - Syndromes of the twentieth century. J Clin Endocrinol Metab 83:2617-2620.

The European Consortium on MEN1 (1997). Identification of the multiple endocrine neoplasia type 1 (MEN1) gene. Hum Molec Genet 6:1177-1183.

Tomassetti P, Cometa G, Del Vecchio E, Baserga M, Faccioli P, Bosoni D, Paolucci G, and Barbara L (1995). Chromosomal instability in multiple endocrine neoplasia type 1: Cytogenetic evaluation with DEB test. Cancer Genet Cytogenet 79:123126.

Villanueva A, Reyes G, Cuatrecasas M, Martinez A, Erill N, Lerma E, Farre A, Lluis F, and Capella G (1996). Diagnostic utility of K-ras mutations in fine-needle aspirates of pancreatic masses. Gastroenterology 110:1587-1594.

Wang $\mathrm{H}$, Xie Z, and Scott RE (1996). Differentiation modulates the balance of positive and negative Jun/AP-1 DNA binding activities to regulate cellular proliferative potential: Different effects in nontransformed and transformed cells. J Cell Biol 135:1151-1162. 